\title{
DISTURBANCES IN THE SIZE OF VARIOUS METABOLIC POOLS OF SOME ISOLATED SOIL ALGAL SPECIES IN RESPONSE TO HEAVY METAL TOXICITY
}

\author{
Awatief F. Hifney ${ }^{1}$, Ahmed A. Issa ${ }^{1}$, Mahmoud S. Adam ${ }^{1}$, Amr A. \\ Al-Abssy ${ }^{2}$

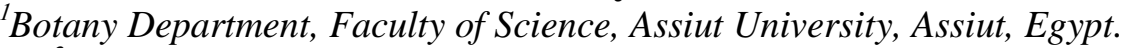 \\ ${ }^{2}$ Botany Department, Faculty of Science, Taiz University, Taiz, Yemen.
}

\begin{abstract}
The growth and some metabolic activities of the five species namely Chlamydomonas reinhardtii (Dang), Chlorococcum humicola (Nag), Scenedesmus obliquus (Turp) Kütz (green algae) and Anabaena circinalis (Rabh.) and Wollea saccata (Wollea Bornet and Flahault) (Blue-green algae) isolated from soil at Assiut, Egypt were investigated under various concentrations of $\mathrm{Cd}^{2+}, \mathrm{Ni}^{2+}$ and $\mathrm{Pb}^{2+}$. The growth of the $C$. reinhardtii, $C$. humicola and S. obliquus were inhibited by all used heavy metals. The highest inhibitory effect was exerted by $\mathrm{Ni}^{2+}$ or $\mathrm{Cd}^{2+}$, while the lowest toxicity was exerted by $\mathrm{Pb}^{2+}$. However, the growth was enhanced by low and medium concentrations of $\mathrm{Pb}^{2+}$. The toxicity of heavy metals for C. reinhardtii, C. humicola, S. obliquus and W. saccata was as follows $\mathrm{Ni}^{2+}>\mathrm{Cd}^{2+}>\mathrm{Pb}^{2+}$. In case of A. circinalis the toxicity of heavy metal was as follows $\mathrm{Cd}^{2+}>\mathrm{Ni}^{2+}>\mathrm{Pb}^{2+}$. Soluble sugars, soluble protein, free amino acids and proline of all species, exhibited a high significant increase with all tested heavy metals supplemented. Insoluble carbohydrates, were generally lowered in various treatments, of heavy metals irrespective the test algae.
\end{abstract}

Key word: Green algae, Blue green algae, $\mathrm{Cd}^{2+}, \mathrm{Ni}^{2+}, \mathrm{Pb}^{2+}$.

\section{Introduction}

Cadmium $\left(\mathrm{Cd}^{2+}\right)$ and Nickel $\left(\mathrm{Ni}^{2+}\right)$ are widely used in a variety of industrial processes, including plastic manufacturing, electroplating, and as well as in paints (Siripornadulsil et al., 2002). In soils, $\mathrm{Cd}^{2+}$ is found in various forms and speciation (Adriano, 1986). Beginning with exchangeable phase where absorption of $\mathrm{Cd}^{2+}$ by electrostatic altercation to negatively charged exchange sites on clays, organic particles, and hydroxyl oxides occurred. Then absorption with oxides, hydroxides and hydrous oxides observed in reducible phase followed by carbonate phase; organic phase; lattice phase; sulfide phase and finally soluble 
phase which exists in soil solution in either the ionic or complexes forms (Cook and Morrow, 1995; Yaron et al., 1996). The toxicity and accumulation of $\mathrm{Cd}^{2+}$ by algae have been reviewed recently (Robidoux $\boldsymbol{e t}$ al., 2004; Andrade $\boldsymbol{e t}$ al., 2005; Iman et al., 2008). Cadmium inhibits cell division and biomass. Motility can be lethal for algae, the toxicity of $\mathrm{Cd}^{2+}$ is depended on both the organism and toxicity criteria employed although specific trend is senility are difficult to identify.

In soils all over the world the average concentration of nickel $\left(\mathrm{Ni}^{2+}\right)$ is probably $20 \mathrm{mg} / \mathrm{kg}$ (20 ppm), which obscures much variation between soil types (McGrath, 1987). A considerable variations of $\mathrm{Ni}^{2+}$ concentration may occurred due to the parent material as well as anthropogenic sources, including metal smelting, sewage sludge disposal, phosphate rock used as fertilizer and the mining (McGrath, 1995). Rashed et al. (1995) gave a range of 21 to $44 \mathrm{ppm}$ as the $\mathrm{Ni}^{2+}$ content of alluvial soils in the Nile Delta, Egypt with an average of $32 \mathrm{ppm}$ for total content and from 0.38 to $1.34 \mathrm{ppm}$ with an average of $0.66 \mathrm{ppm}$ for available form. In Assiut City the average concentration of $\mathrm{Ni}^{2+}$ was $0.22 \mathrm{ppm}$ in unpolluted soils (Issa et al., 2006).

Lead $\left(\mathrm{Pb}^{2+}\right)$ is a well-known pervasive chemical and is known for its toxicity. The major environmental sources of metallic lead and its salts are paint, autoexhaust, food and water. The soil adjacent to highways had lead accumulation in the range of 128 to $700 \mathrm{ppm}$ decreased with distance from traffic and with soil depth (Kelemen and Csordas, 1994). The situations of $\mathrm{Pb}^{2+}$ in some Egyptian soils are reported by El-Molla (1980). He found that, $\mathrm{Pb}^{2+}$ content varied from 71 to $226 \mathrm{ppm}$ in the surface soils adjacent to Cairo-Alexandria highway. ElGharably (1993) recorded that the $\mathrm{Pb}^{2+}$ contents of sewage sludge collected from different sites in Assiut 9 City ranged from 35 to $38 \mathrm{ppm}$, and the unpolluted soils ranged from 0.08 to $0.15 \mathrm{ppm}$. Lead tends to accumulate to high extent in algae. $\mathrm{Pb}^{2+}$ was found to be sequestered in polyphosphate bodies of the blue-green algae (Plectonema boryanum) and in cell sectors with polyphosphate bodies of green algae Chlorella saccharophila and diatoms Navicula incerta and Nitzschia closterum (Jensen et al., 1982). Wehr and Whitton (1983) reported the growth of some algae species (e.g. blue-green algae Phormidium autumnale, Aphanocapsa sp., Pseudoanabaena catenata, diatoms Achnanthes minutissima, Navicula tantula, Calonies bacillum, Cymbella bipartita or green algae Mougeotia sp. and Hormidium rivulare) in waters with elevated lead concentrations. Say and Whitton (1982) reported the growth of a blue-green alga Schizothrix sp. in close association with anglesite $\left(\mathrm{PbSO}_{4}\right)$, the concentration of $\mathrm{Pb}^{2+}$ in the sediment having been $110 \mathrm{~g} \cdot \mathrm{kg}^{-1}$.

In Egypt and other countries, irrigation with sewage wastewater, sedimentation of sludge material and deposition of air-born particulates on plants and soils are probably the most important source of soil and plant contamination with heavy metals, particularly near industrial zones. These pollutants affect on 
algal growth and metabolic activities. This study aimed to follow the growth as well as the metabolic activities of the three green algae $(C$. reinhardtii, $C$. humicola and S.obliquus and two cyanobacteria (A. circinalis and W. saccata isolated from soil of different $\mathrm{Cd}^{2+}, \mathrm{Ni}^{2+}, \mathrm{Pb}^{2+}$ concentrations.

\section{Materials and Methods}

Three species of green algae (C.reinhardtii, C. humicola and S. obliquus) and two blue-green algae A. circinalis and W. saccata were isolated from selected soils contaminated with heavy metals at Assiut Governorate (for details of the algae under testing and for description of these polluted soil see (Issa $\boldsymbol{e t}$ al., 2006). The effects of $(0.05,0.1,0.2 \mathrm{mM}$ expressed as low, medium, high concentrations of $\mathrm{Cd}^{2+}, \mathrm{Ni}^{2+}$ and $\mathrm{Pb}^{2}$ on the algal growth as well as some metabolic activities were assessed.

All algal species were cultivated in batch culture treated with various concentrations of $\mathrm{Cd}^{2+}, \mathrm{Ni}^{2}, \mathrm{~Pb}^{2}$ (For details see Issa et al., 2006).

The isolated blue green algae were cultured using a modified blue green algal medium BG-11 (Rippka and Herdman, 1993). While the isolated green algae were cultured using a Bold's Basal medium (Bischoff and Bold, 1963). The addition of the heavy metals treatments did not exert a large change in the $\mathrm{pH}$ of the medium. All cultures started with a $\mathrm{pH}$ of 7.1 and remained unchanged for one week. 3300 Walt tungsten lamp were used for illumination at room temperature.

The growth rate and generation time of each tested algal species was grown with various concentrations of heavy metals were followed by daily measurements of absorbance at $750 \mathrm{~nm}$ as described by Lefort-Tran $\boldsymbol{e t}$ al. (1988). Optical density was used as a parameter for algal growth. The growth rate $\mu\left(d^{-1}\right)$ was determined from the following formula:

$$
\mu\left(\mathrm{d}^{-1}\right)=\frac{\ln \mathrm{N}_{1}-\ln \mathrm{N}_{0}}{\mathrm{t}_{1}-\mathrm{t}_{0}}
$$

Where

$\mathrm{N}_{1}=$ Optical density at time $\mathrm{t}_{1}$.

$\mathrm{N}_{0}=$ Optical density at time $\mathrm{t}_{0}$.

$t_{1}-t_{0}=$ The time elapsed in days between two determinations of optical density.

While the generation time $\mathrm{G}$ (doubling of optical density) can be calculated as follows:

$$
\mathrm{G}=\frac{\ln 2}{\mu} \mathrm{d}
$$

Egyptian J. of Phycol. Vol. 11, 2010 
After 7 days, the algal cells were harvested for measuring the growth and some metabolic estimation, in the late of exponential phase or beginning of the stationary phase according to the algal growth curve. The cell numbers (in case of green algae) were determined by counting of cell number microscopically using 1 $\mathrm{mm}$ deep haemocytometer slide. For determination of dry weight, $10 \mathrm{ml}$ of algal culture, after filtered through glass fiber filter paper, was dried for two hours in oven at $105^{\circ} \mathrm{C}$. The data were given as $\mathrm{mg} \cdot \mathrm{ml}^{-1}$ algal culture.

Pigments represented by chlorophyll a ( $c h l a)$ and chlorophyll b (chl b) were estimated in green algal species, while chlorophyll (chl $a$ ) only was measured in blue green algal species by extracting in hot methanol at $70^{\circ} \mathrm{C}$ for 10 minutes (Marker, 1972; Metzner et al., 1965). The photosynthetic activity was measured polargraphically as oxygen evolution using a Clark type electrode $\left(\mathrm{O}_{2}\right.$ Meter CG867, Germany). The data obtained were calculated as $\mu$ moles $\mathrm{O}_{2} / \mathrm{mg}$ chlorophyll/hour. Respiration was measured in the dark as $\mathrm{O}_{2}$-uptake in the same sample. The anthrone sulphuric acid method (Fales, 1951; Schlegel, 1956 and Badour, 1959) was used for the determination of all carbohydrate including polysaccharides. While soluble, insoluble and total proteins were measured according to Lowry et al. (1951). Free amino acids were extracted from algal suspension and determined according to the method of Lee and Takahashi (1966). Proline was determined according to the method of Bates et al. (1973). The data was obtained by four independent experiments and measured as means \pm standard error (SE)

\section{Results and Discussion}

Comparing the results to the control (no heavy metals added) the growth rates of the $C$. reinhardtii, $C$. humicola, $S$. obliquus and $W$. saccata were inhibited by all applied heavy metals.

The highest inhibitory effect was detected by $\mathrm{Ni}^{2+}$ and $\mathrm{Cd}^{2+}$ while the lowest toxicity was exerted by $\mathrm{Pb}^{2+}$ (Figs. 1, 2, 3, 4 and 5). Meanwhile, the growth rate of A. circinalis was enhanced by low and medium concentrations of $\mathrm{Pb}^{2+}$ (Fig. 4). The growth rate as well as minimum generation time was recorded for all tested species and control cultures. Rachlin et al. (1983) recorded 50\% reduction of growth of Navicula by certain concentrations of $\mathrm{Cd}^{2+}, \mathrm{Co}^{2+}, \mathrm{Pb}^{2+}$ and $\mathrm{Zn}$. While the growth rate of Kirchneriella lunaris was inhibited by $\mathrm{Cd}^{2+}, \mathrm{Mn}^{2+}, \mathrm{Ni}^{2+}$ and $\mathrm{Co}^{2+}$ (Issa et al., 1995). On the other side, El-Enany and Issa (2000) stated that the growth of Nostoc linckia and Nostoc rivularis were showed a significant stimulation in low waste treatments compared to control culture, not only for the number of cells but also, the time required to reach the exponential and the stationary phases. 

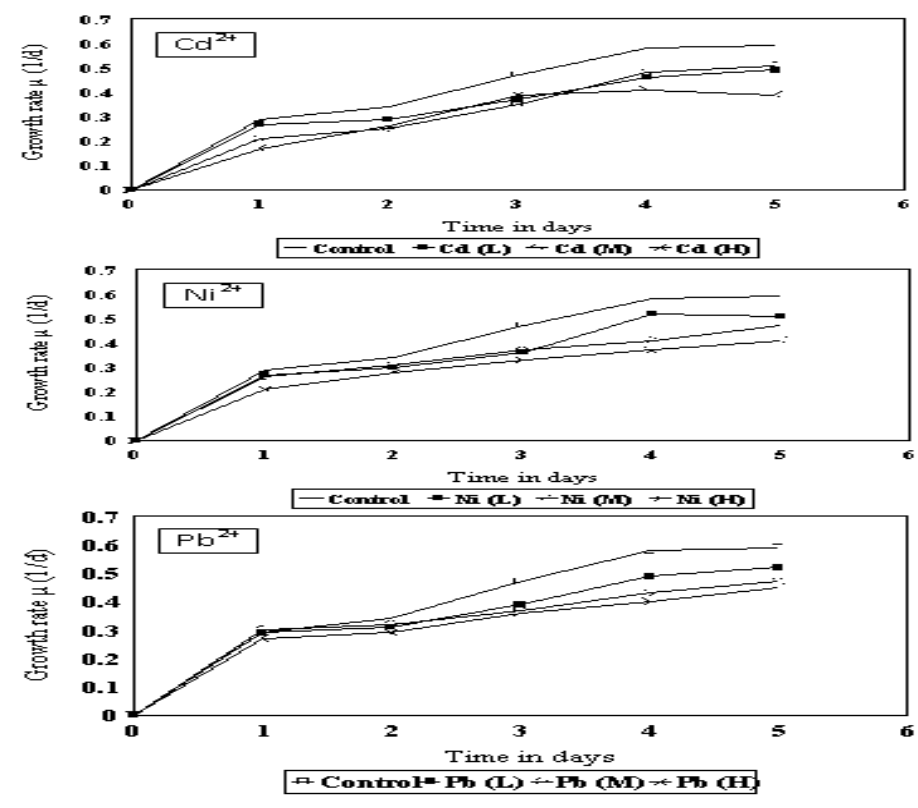

Figure (1): Growth rate of Chlamydomonas reinhardtii under various heavy metals concentrations. Values are means of three replicates; ES. is smaller than the symbol in all cases.
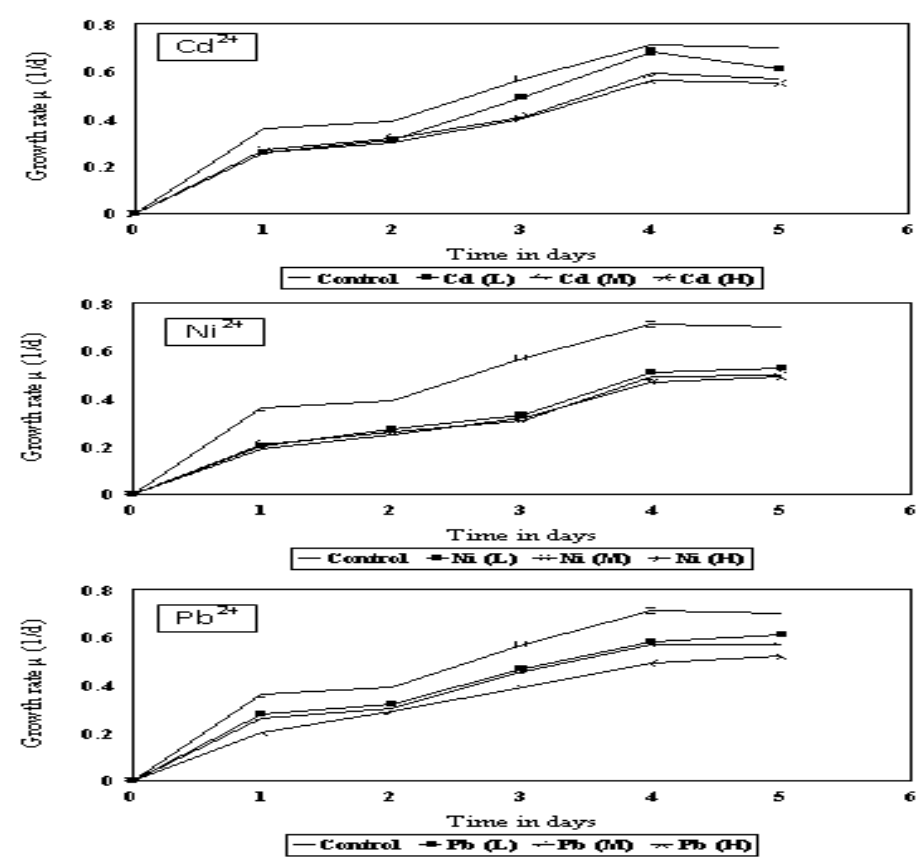

Figure (2): Growth rate of Chlorococcum humicola under various heavy metals concentrations. Values are means of three replicates; SE. is smaller than the symbol in all cases. 
Awatief F. Hifney et al.
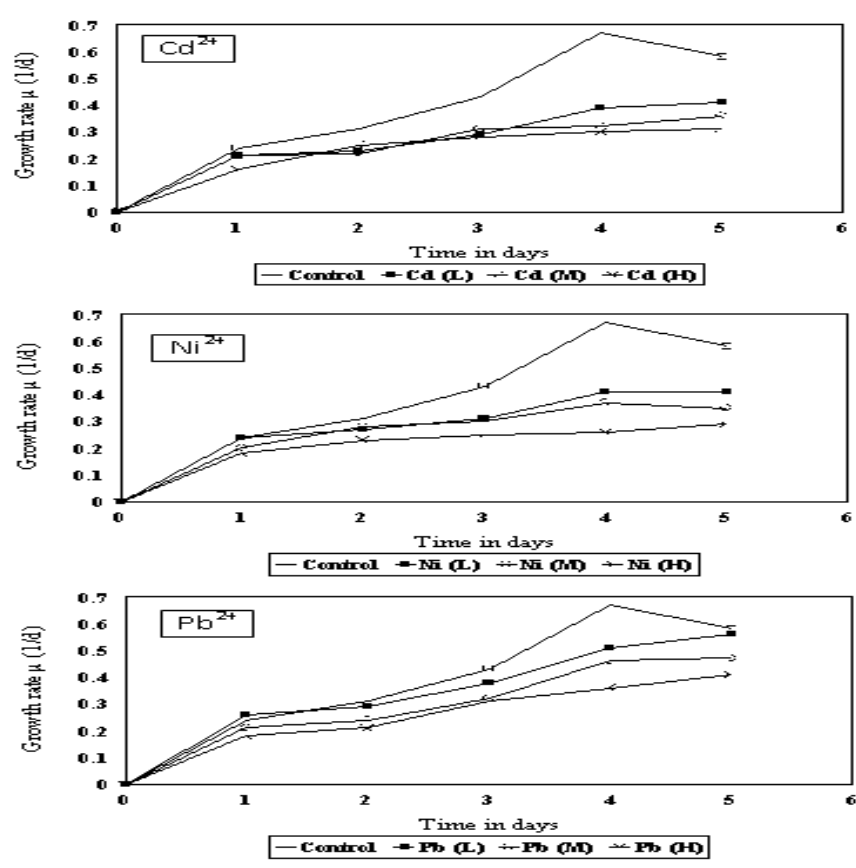

Figure (3): Growth rate of Scenedesmus obliquus under various heavy metals concentrations. Values are means of three replicates; s.e. is smaller than the symbol in all cases.
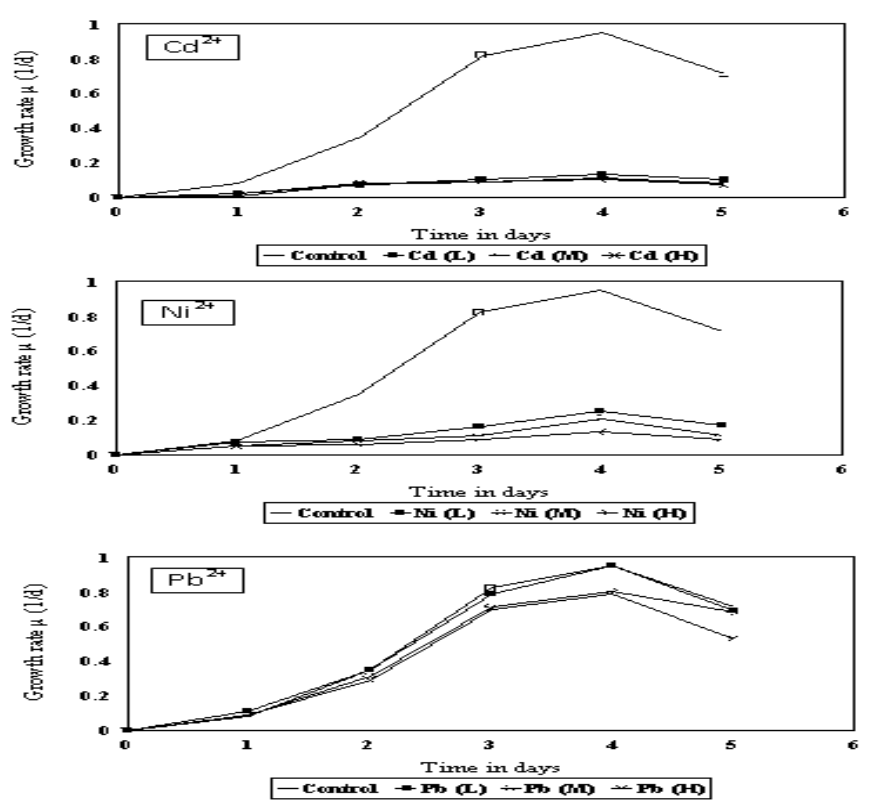

Figure (4): Growth rate of Anabaena circinalis under various heavy metals concentrations. Values are means of three replicates; s.e. is smaller than the symbol in all cases. 

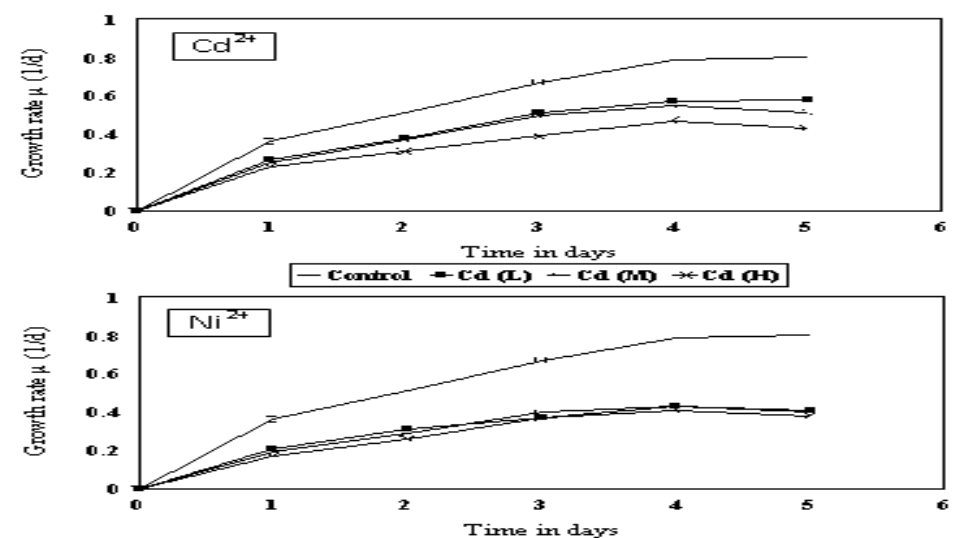

Figure (5): Growth rate of Wollea saccata under various heavy metals concentrations. Values are means of three replicates; $\mathrm{SE}$ is smaller than the symbol in all cases.

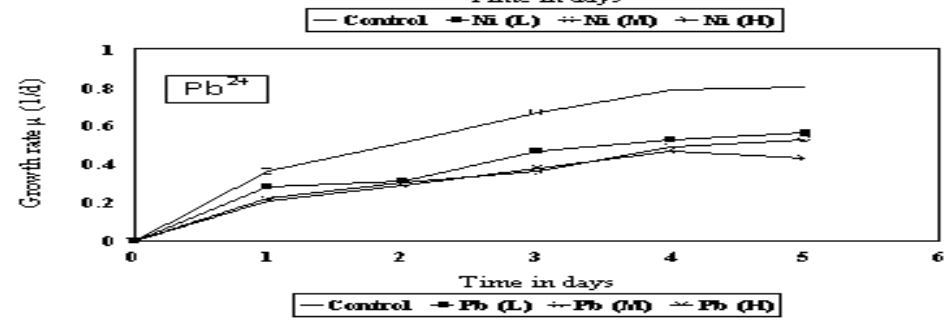

However, high concentration of wastes reduced growth of the two species tested.

In general, cell number, chlorophyll a, b and dry matter of $C$. reinhardtii, C. humicola and $S$. obliquus were markedly decreased with increasing heavy metals concentration (Table 1-3). However, $\mathrm{Ni}^{2+}$ and $\mathrm{Cd}^{2+}$ appear to have a serious effect on pigments. Also, the contents of chlorophyll a and dry matter of A. circinalis and $W$. saccata were generally decreased in $\mathrm{Cd}^{2+}$ and $\mathrm{Ni}^{2+}$ concentrations (Tables 4 and 5). In $\mathrm{Pb}^{2+}$ treated cultures, chlorophyll a of $W$. saccata was slightly increased and the dry matter was almost unchanged. The toxicity of heavy metals for $C$. reinhardtii, C. humicola, S. obliquus and $W$. saccata was as follows $\mathrm{Ni}^{2+}>\mathrm{Cd}^{2+}>\mathrm{Pb}^{2+}$. In case of A. circinalis the toxicity of heavy metals was as follows $\mathrm{Cd}^{2+}>\mathrm{Ni}^{2+}>\mathrm{Pb}^{2+}$. Sabnis et al. (1969) attributed that chlorophyll damage on the thylakoid membrane could be due to the affinity of heavy metals. Issa et al. (1998) stated that, the pigment fractions of Kirchneriella lunaris and Scenedesmus obliquus under various heavy metals were significantly decreased. Moreover, nickel and manganese were very toxic to pigment fractions. The reduction of chlorophyll may be due to sensitivity of the enzymes of chlorophyll biosynthesis towards heavy metals ions (Abdel-Basset $\boldsymbol{e t}$ al., 1995).

Photosynthetic $\mathrm{O}_{2}$ evolution and respiratory oxygen uptake of the five species tested were also affected by these treatments. While the photosynthetic $\mathrm{O}_{2}$ evolution was reduced proportionally to metal toxicity, and the respiratory oxygen uptake was enhanced by heavy metals applied. This results in accordance with Mendoza-Cozatletal (2002). 
Generally, $\mathrm{Cd}^{2+}$ or $\mathrm{Ni}^{2+}$ have a serious effect on $\mathrm{O}_{2}$ exchanges depending on the species tested. Green algae were highly tolerant to heavy metals than bluegreen algae under these treatments (Tables 1-3). The toxic effects of $\mathrm{Cd}$ in Euglena gracils include inhibition of growth, motility, phototaxis and photosynthesis (Mendoza-Cozatl et al., 2002). Cadmium is more toxic than zinc to the growth and photosynthetic $\mathrm{O}_{2}$ evolution of Anabaena variabalis (Attridge and Rowell, 1997; Axtell et al., 2003). Takamura et al. (1989) stated that, Cyanophyceae are sensitive to cupper, cadmium, zinc metals than other algae tested (green algae or diatoms) for photosynthetic activity, through the inhibition of photosystem II and/or reduction the four enzymes involved in the fixation of $\mathrm{CO}_{2}$ for at least the first 2 days of the exponential growth.

As a result, the pool size of soluble sugars of the five species tested, exhibited a high significant increase by heavy metals $\left(\mathrm{Cd}^{2+}, \mathrm{Ni}^{2+}\right.$ and $\left.\mathrm{Pb}^{2+}\right)$ supplemented. Insoluble carbohydrates were generally lowered in various treatments, irrespective (Tables1-5). The same results was obtained by Adam (1995) using the green algae Kirchneriella lunaris and Lead as heavy metals. Hellebust (1965) reported that Phaeodactylum secretes up to $7 \%$ of the total assimilation carbon, some of which are polysaccharides liberated from the cell surface, which in turn act as binding agents for lead. The level of storage carbohydrates was raised at low $\mathrm{Cd}^{2+}$ concentrations, while at high concentration the opposite was obtained (Greger and Bertell, 1992). Furthermore, the accumulation of saccharides exerts feedback inhibition of photosynthesis or even triggers gene expression resulting in lower activities of ribolose 1, 5 bisphosphate carboxylase/oxygenase (Issa et al., 2002).

Similarly, the contents of soluble proteins in all five species tested were raised under heavy metals treated cultures (Tables 1-5). The elevation of soluble proteins at the expense of insoluble proteins generally indicates an inhibition in the growth efficiency by heavy metals supplemented. The toxicity of heavy metals was as follows $\mathrm{Cd}^{2+}>\mathrm{Ni}^{2+}>\mathrm{Pb}^{2+}$. Total protein contents were mostly found to be generally lowered under conditions of stress (Yupsanis et al., 1994). While soluble proteins were found to be raised when the plants were exposed to stress conditions (Xu et al., 1996). Such elevation of soluble protein contents was mostly ascribed to a decline in the content of relatively higher molecular proteins (Pelah et al., 1997). Algae detoxify heavy metals via metal-binding proteins of low molecular weight and high cysteine and metal content (Zenk, 1996). Furthermore, metallothionein proteins have been postulated to play a role in the detoxification of heavy metals (Vitarella et al., 1996 and El-Enanay and Issa, 2000).

In parallel, free proline and free amino acids were significantly accumulated in the tested algal species by all heavy metals applied. The highest values of proline and free amino acids were recorded in A.circinalis and $W$. 
Disturbances in the size of various metabolic pools of some isolated soil algal species in response

\begin{tabular}{|c|c|c|c|c|c|c|c|c|c|c|c|}
\hline \multicolumn{3}{|c|}{$\nabla_{7}^{7}$} & \multicolumn{3}{|c|}{$\underset{i}{z}$} & \multicolumn{3}{|c|}{$\frac{2}{7}$} & \multirow{2}{*}{$\stackrel{\hat{\rho}}{\hat{3}}$} & \multirow{2}{*}{\multicolumn{2}{|c|}{ Treatment }} \\
\hline$=$ & 3 & $F$ & \pm & 3 & $r$ & \pm & 3 & $r$ & & & \\
\hline $\begin{array}{l}P \\
0 \\
0\end{array}$ & 䓂 & 蒙吉 & 䓂 む & 密 & $\underbrace{+}_{t}$ & 葛 & 莣: & 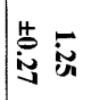 & 营 행 & \multicolumn{2}{|c|}{$\begin{array}{l}\text { Cell No. } \\
\text { Cell.mI } I^{-1 *} 0^{3}\end{array}$} \\
\hline$\dot{i}$ & i & 婇 & $\dot{E}$ & $\dot{H}$ & 总 & $\dot{E}$ & 茫 & fi & : & \multicolumn{2}{|c|}{$\mu\left(d^{-1}\right)$} \\
\hline is & $E$ & $\bar{\omega}_{\omega}$ & 5 & $\dot{t}$ & $\bar{\omega}_{\omega}$ & ì & $\dot{\tilde{\alpha}}$ & 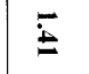 & $\dot{\vec{j}}$ & \multicolumn{2}{|r|}{$G\left(d^{-1}\right)$} \\
\hline$\frac{1}{6}$ & 告: & 㟥 & 葛 & 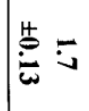 & 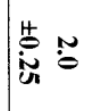 & $\stackrel{+}{\stackrel{ \pm}{\omega}}$ & 浐: & ث & $\underset{\dot{\omega}}{\stackrel{4}{*}}$ & \multicolumn{2}{|c|}{$\begin{array}{l}\text { Dry wt. } \\
\mathrm{mg} \mathrm{ml}^{-1}\end{array}$} \\
\hline 晜 & 草 & 苦: & 莫 & 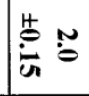 & 告 & : & 蓄 & 蒡 & 荠 & \multicolumn{2}{|c|}{ Chl. a $\mu \mathrm{g} \mathrm{ml}^{-1}$} \\
\hline 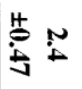 & $\underset{\text { W }}{+}$ & 莣 & 萻 & 芦 & W & $\stackrel{H}{\stackrel{*}{*}}$ & 葛: & 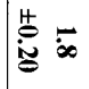 & $\stackrel{H}{\stackrel{H}{*}}$ & \multicolumn{2}{|c|}{ Chl. b $\mu \mathrm{g} \mathrm{ml}^{-1}$} \\
\hline$\stackrel{i}{i}_{\infty}^{+\infty}$ & 莣: & $\underset{ \pm}{+}$ & 葛 & 葛: & 蒡: & 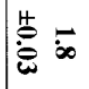 & 蓠 & $\stackrel{+}{\stackrel{*}{2}}$ & 莣 & \multicolumn{2}{|r|}{$\mathrm{O}_{2} \uparrow *$} \\
\hline$\underset{\sim}{*}$ & 莣 & 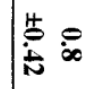 & 蒡 & 苍 : & 葛: & : & 莣: & $\begin{array}{l}\text { 告 } \\
\dot{b} \\
\end{array}$ & ${ }_{i=}^{+}=$ & \multicolumn{2}{|r|}{$\mathrm{O}_{2} \downarrow *$} \\
\hline 熟 & 䓂 & 䓂山 & 葛 & 范 & $\stackrel{\Delta}{\dot{\theta}} \pm$ & 䓂 & 䓂 & 䓂 & 售士 & \multirow{8}{*}{ 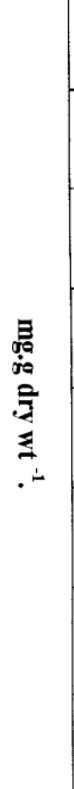 } & S.C. \\
\hline$\stackrel{+}{\dot{\theta}}=$ & 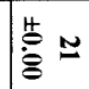 & 瞢 N & 㟥 & 荁 & 浐 & $\stackrel{+}{\stackrel{\theta}{\theta}}+$ & 浐 & 浐a & $\stackrel{t}{\stackrel{4}{\ominus}}$ & & Ins. C. 唹 \\
\hline 蓠名 & 䓂告 & 䓂 & 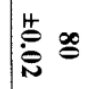 & $\stackrel{+}{\stackrel{*}{0}}$ & 密 & 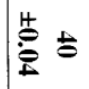 & 㟥出 & 葛 出 & 葛 & & T.C. \\
\hline 蓄= & 葛 & 葛 6 & 䓂 & 暮 & $\stackrel{+}{\stackrel{*}{8}}=$ & 葛 $\infty$ & $\stackrel{+}{\stackrel{+}{=}=}$ & 䓂 & 。 & & S.P. \\
\hline 葛 & 葛 & 浐 & 苍 & 蓠的 & 㟥 & 葛 & 等 & $\stackrel{\Delta}{\dot{\theta}} \infty$ & 葛 & & Ins.P. P. \\
\hline$\stackrel{+}{9}$ & 葛 & 㟥出 & 葛 & 葛 & $\stackrel{H}{\stackrel{\theta}{8}}$ & 葛 & 萨 & 荌 & 䓂出 & & T.P. \\
\hline 蒂 & 告岕 & 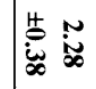 & 告 & 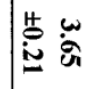 & 营管 & $\begin{array}{l}\stackrel{H}{0} \\
\stackrel{*}{=}\end{array}$ & 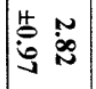 & فِ & 俈 & & A.A. \\
\hline 䓂离 & 蓄莡 & 泀萓 & 㟥 & 䓂葛 & 葛营 & 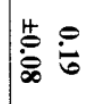 & 葛: & 蓄客 & $\underset{\infty}{+}$ & & Proline \\
\hline
\end{tabular}




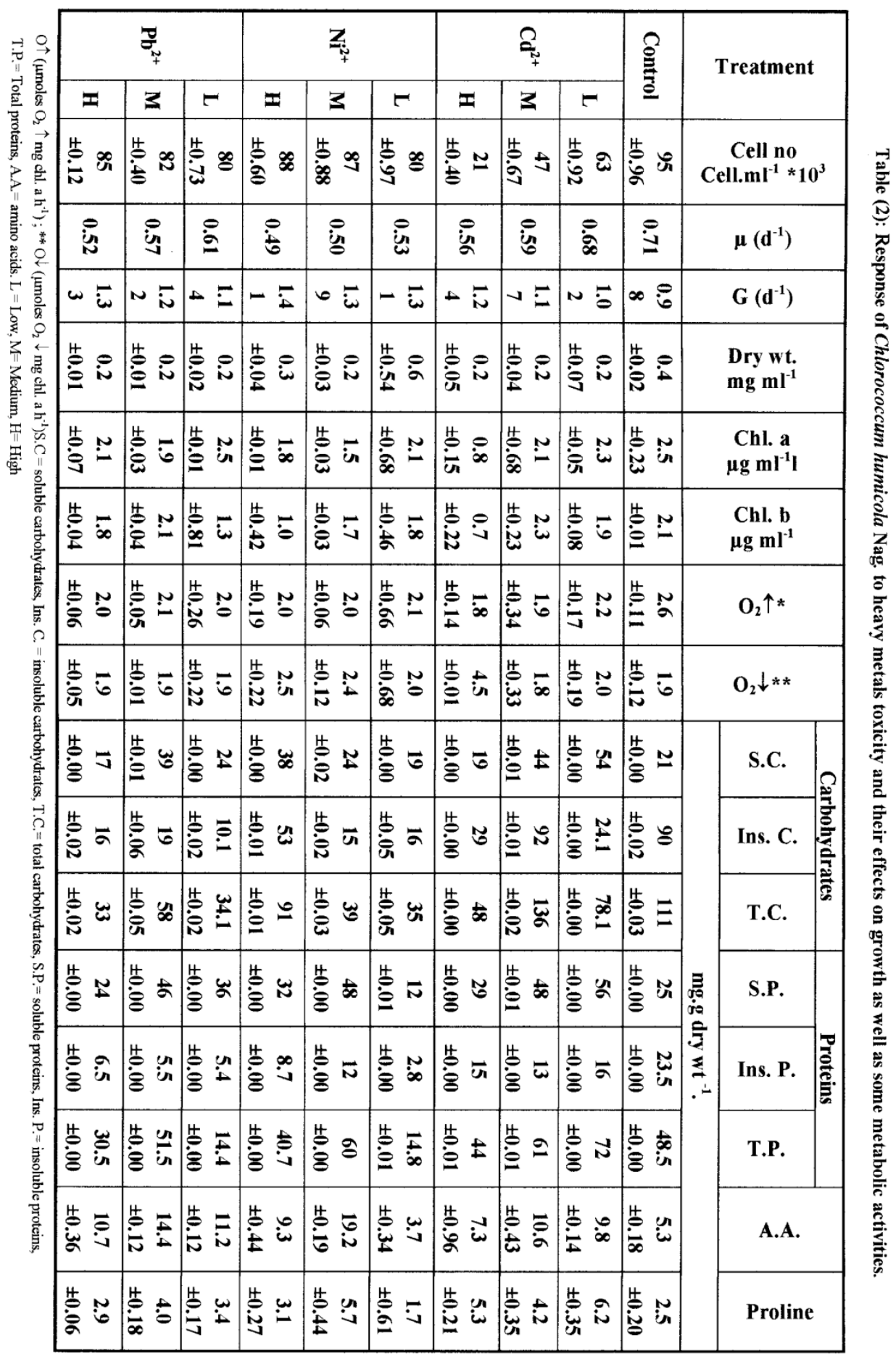




\begin{tabular}{|c|c|c|c|c|c|c|c|c|c|c|}
\hline \multicolumn{3}{|c|}{$\bar{T}_{\overline{7}}$} & \multicolumn{3}{|c|}{$\underset{7}{Z}$} & \multicolumn{3}{|c|}{$\hat{~}$} & \multirow{2}{*}{ 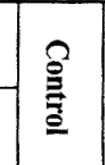 } & \multirow{2}{*}{ Treatment } \\
\hline \pm & 3 & $r$ & \pm & 3 & $r$ & \pm & 3 & $r$ & & \\
\hline 营 & 蒙要 & 萑 & 蒡ळ & 䓂 & 尊 & 葛 & 䓂 & 䓂 & 䓂 & $\begin{array}{c}\text { Cell no } \\
\text { Cell.ml }{ }^{1}{ }^{*}{ }^{3} 0^{3}\end{array}$ \\
\hline$\dot{E}$ & $\dot{H}$ & $\dot{E}$ & 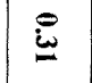 & జू. & $\stackrel{8}{=}$ & $\stackrel{E}{\dot{E}}$ & $\dot{\xi}$ & $\dot{E}$ & $\dot{s}$ & $\boldsymbol{\mu}_{\mathrm{x}}\left(\mathbf{d}^{-1}\right)$ \\
\hline$\dot{\hat{\theta}}$ & $\dot{4}$ & $\dot{8}$ & $\tilde{n}$ & $\vec{\omega}$ & $\hat{\theta}$ & $\stackrel{\mathfrak{n}}{\tilde{N}}$ & $\overrightarrow{\dot{\omega}}$ & $\dot{8}$ & $\overrightarrow{\dot{\omega}}$ & $\mathbf{G}\left(\mathbf{d}^{-1}\right)$ \\
\hline$\stackrel{4}{0}:$ & : & 雚 & 莣市 & 蒡市 & 蓄 $\bar{\omega}$ & 蒡: & 蓄吊 & 蓄: & 莣它 & $\begin{array}{l}\text { Dry wt. } \\
\text { mg ml }^{-1}\end{array}$ \\
\hline 㷛: & 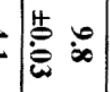 & 俈: & 莹: & 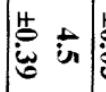 & 告 & 吢 & $\mid \begin{array}{c}\mathrm{H} \\
0\end{array}$ & 蒂 & 葶吉 & $\underset{\mu \mathrm{g} \mathrm{m} \mathbf{l}^{-1}}{\mathrm{Chl}}$ \\
\hline N & 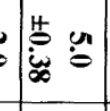 & 萃 & 蓄 $\bar{i}$ & 蒡: & $\underbrace{*}_{\mathbb{\infty}}$ & 芦 & 荧: & 蓠 & 蓄 & $\begin{array}{c}\text { Chl. b } \\
\mu \mathrm{g} \mathrm{m} \mathbf{l}^{-1}\end{array}$ \\
\hline 莍: & 营造 & 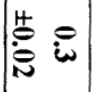 & 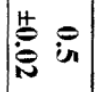 & 尝: & 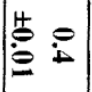 & $\mid \begin{array}{ll}4 & : \\
0 & :\end{array}$ & 党: & 䓂: & 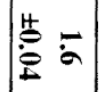 & $\mathbf{O}_{2} \uparrow *$ \\
\hline 党: & 裳: & 蒡 : & 蓄 & 党 证 & 嚄 & $\mid \begin{array}{cc}* \\
\tilde{z}\end{array}$ & 告: & 䓂: & 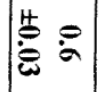 & $\mathrm{O}_{2} \downarrow{ }^{* *}$ \\
\hline ב & 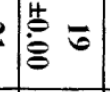 & 䓂 & w & 葛 & 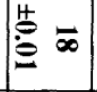 & 䓂 & 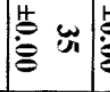 & 俈 & 蒡 & \\
\hline$\stackrel{4}{*}$ & $\frac{10}{8}=$ & 毫 & 蒡 & 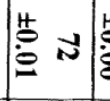 & 葛 & 䓂 & 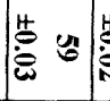 & 䓂 & 营我 & Ins. C. \\
\hline 荌 & 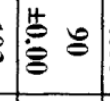 & 䓂= & 薑 & 蒙。 & 葛品 & a & 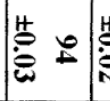 & 营 & 䓂三 & T.C. \\
\hline 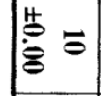 & 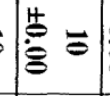 & 葛 & 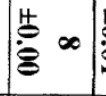 & 告 & 18 & 营必 & 蒙 & 䓂 & 葛 & S.P. \\
\hline 暮 & $\mid$ & 雚 6 & 葛 & 嚄 & 1 & 㟟分 & 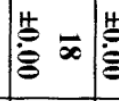 & 䓂苏 & 雚 & 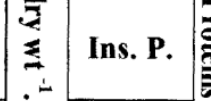 \\
\hline 葛出 & 葛它 & 蒡 & 蒡 $\approx$ & 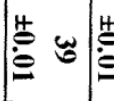 & 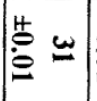 & 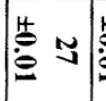 & 䓂 & 葶 & 葛出 & T.P. \\
\hline 密莣 & 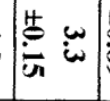 & 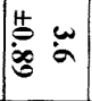 & 苦 & 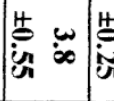 & $\underbrace{*}_{i=i} \underset{i}{\infty}$ & 莒: & 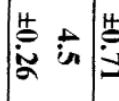 & 蒡荡 & 葛 & A.A. \\
\hline 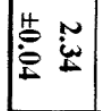 & 8 & $\bar{N}$ & $\infty$ & 蓄 & 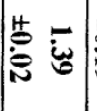 & $\mid \begin{array}{ll}4 \\
0 \\
\end{array}$ & 䓂 & 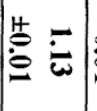 & 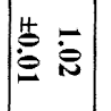 & Proline \\
\hline
\end{tabular}




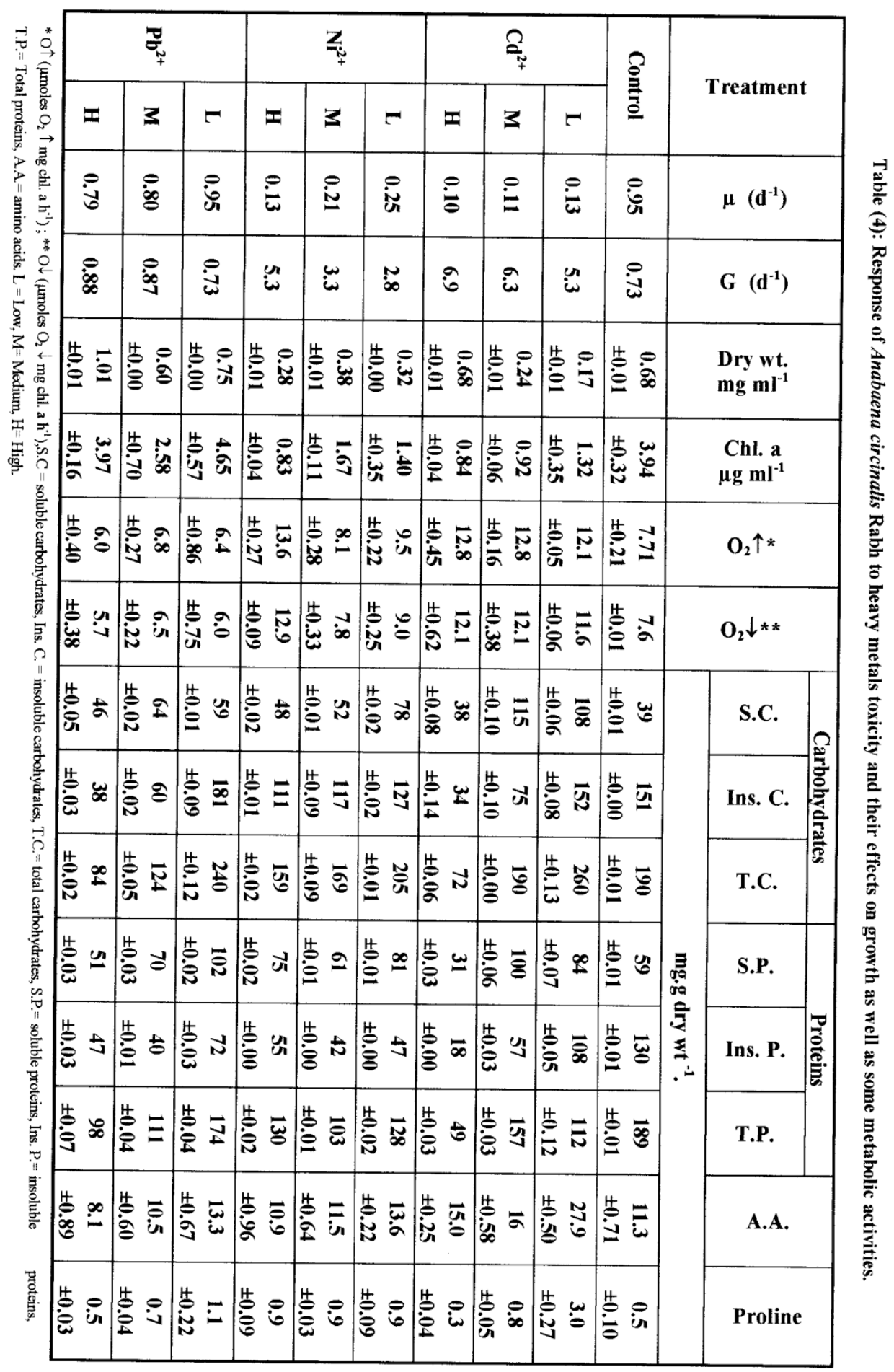




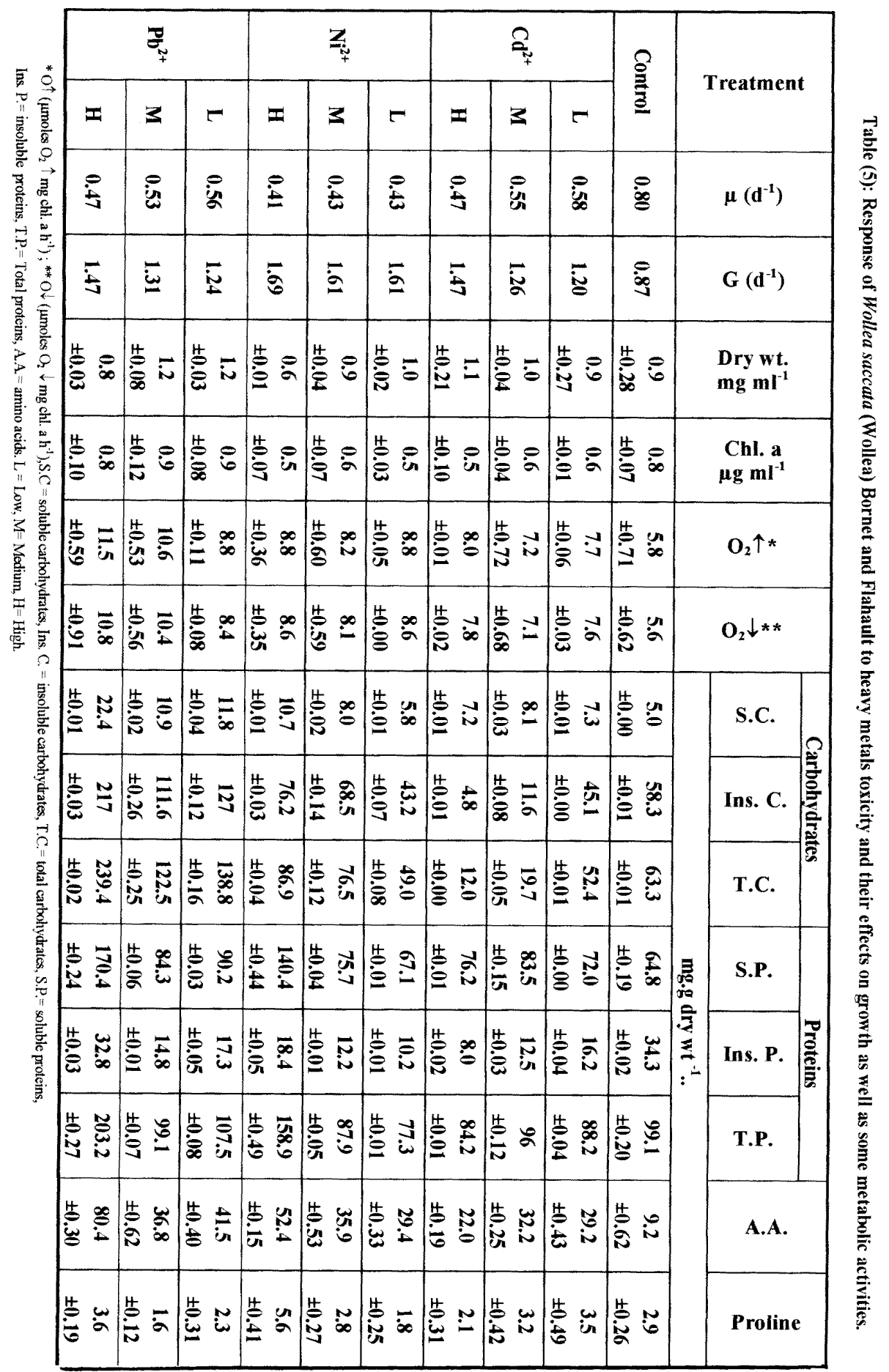


saccata and the lowest one in S. obliquus (Tables 1-5). Proline has been reported to be accumulated in tissues and/or organs of plant subjected to drought, salt, temperature, heavy metals stress, or infected by some pathogens in plants (Nikolopoulos and Manetas, 1991; Alia Saradhi, 1992). Proline inhibits metalinduced loss of potassium ions in Chlorella vulgaris and Trebowxia erici (chlorophyta) ( Backor et al. 2004).

Wu et al. (1995 and 1998) mentioned that copper and cadmium treatment enhanced proline accumulation in green algae (Chlorella sp., Pediastrum duplex), the diatom (Nitzschia palea) and a Cyanobacterium (Anacystis nidulans). The relationship between proline level and metal accumulation revealed that the accumulation of free proline corresponds to the uptake of the metals $\left(\mathrm{Cd}^{2+}, \mathrm{Ni}^{2+}\right.$ and $\mathrm{Mn}^{2+}$ ) by Scenedesmus armatus cells (El-Enany and Issa, 2001). Proline accumulation may play a role in heavy metal detoxification (Costa and Morel, 1994); it could be involved in metal chelation in cytoplasm (Farago and Mullen, 1979), especially in the case of metals with a preference for nitrogen or oxygen coordination over phytochelations (Grill et al., 1987).

The overall conclusion of this work is that heavy metals exerted disturbances on the size of various metabolic pools of algae. The degree of disturbance depends upon the metal used and the algal species.

\section{References}

Abdel-Basset, R.; Issa, A.A. and Adam, M.S. (1995). Chlorophyllase activity: effects of heavy metals and calcium. Photosynthetica, 31: 421-425.

Adam, M. S. (1995). After-effect of $\mathrm{Pb}^{2+}$ on carbohydrates and nitrogen fractions of the unicellular green alga Kirchnerilla lunaris in the presence of $\mathrm{Ca}^{2+}$. Bull. Fac. Sci., Assiut Univ., 24: 113-121.

Adriano, D.C. (1986). Trace elements in the terresterial environment SpringerVerlag, Springer pres, New York, 533 pp.

Alia Saradhi, P. (1992). Protein accumulation under metal stress. J. Plant Physiol., 132: 554-558.

Andrade, A.D.; Rollemberg, M.C.E. and Nobrega, J.A. (2005). Proton and metal binding capacity of the green freshwater alga Chaetophora elegans. Process Biochemistry, 40: 1931-1936.

Attridge, E.M. and Rowell, P. (1997). Growth, heterocyst differentiation and nitrogenase activity in the cyanobacteria Anabaena variabilis and Anabaena cylindrica in response to molybdenum and vanadium. New Phytol., 135: 517-526. 
Axtell, N.R.; Sterberg, S.P.K. and Claussen, K. (2003). Lead and nickel removal using Microspora and Lemna minor. Bioresource Technology, 89: 41-48.

Backor, M.; Fahselt, D. and Wu, C.T. (2004). Free proline content is positively correlated with copper tolerance of the lichen photobionat Trebouxia erici (Chlorophyta). Plant Science, 167: 151-157.

Badour, S.S.A. (1959). Analytisch Chemische unter suchung des kalimangels bei Chlorella in vergleich mit anderen manget zamstanden. Ph.D. Dissertation Goettingen.

Bates, L.S.; Waldren, R.P. and Teare, I.D. (1973). Rapid determination of free proline for water-stress studies. Short communication. Plant Soil, 39: 205-207.

Bischoff, H.W. and Bold, H.C. (1963). Phycological studies. 4- Some soil algae from Enchanted rock and related algal species. Univ. Taxas Publ., N. 6318: 32-36.

Cook, M.E. and Morrow, H. (1995). Anthropogenic sources of cadmium in Canada. Natioal Workshop on Cadmium Transport into Plants. Candian Network of Toxicology Centres, Ottawa, Ontario, Canada, June 20-21

Costa, G. and Morel, J.L. (1994). Water relations, gas exchange and amino acid content in $\mathrm{Cd}^{2+}$-treated lettuce. Plant Physiol. Biochem., 32: 561-570.

El-Enany, A.E. and Issa, A.A. (2000). Cyanobacteria as a biosorbent of heavy metals in sewage water. Environ Toxicology and Pharmacology, 8: 95101.

El-Enany, A.E. and Issa, A.A. (2001). Proline alleviates heavy metal stress in Scenedesmus armatus. Folia Microbiol., 46: 227-230.

El-Gharably, G.A.S. (1993). Utilization of wastewaters for agricultural production in Upper Egypt. First Annual Report, 1993.

El-Molla, S.H.H. (1980). Studies on soil and plant pollution with lead. M.Sc. Thesis, Fac. of Agric., Ain Shams Univ., Egypt

Fales, F.W. (1951). The estimation and degradation of carbonhydrates by yeast cell. J. Biol. Chem., 193: 113-118.

Farago, M.E. and Mullen, W.A. (1979). Plants which accumulate metals-IV. A possible copper-proline complex from roots of Armeria maritima. Inorg. Chem. Acta, 32: 193-194.

Greger, M. and Bertell, G. (1992). Effects of $\mathrm{Ca}^{2+}$ and $\mathrm{Cd}^{2+}$ on the carbohydrate metabolism in sugar beet (Beta vulgaris). J. Exp. Bot., 43: 167-173. 
Grill, E.; Winnacker, E.L. and Zenk, M.H. (1987). Phyytochelations, a class of heavy metal-binding peptides from plants, are functionally analogous to metallo-thioneins. Proc. Nat. Acad. Sci., USA, 84: 439-443.

Hellebust, J. A. (1965). Excretion of some organic compounds by marine phytoplankton. Limnol. Oceanogr., 10: 192-206.

Iman,Y. E. Ashmawy, A. and Bader, S.(2008). Bisorption of Cadmium and Nickel by Nile water algae. J. of applied Sciences research, 4:391-396.

Issa, A.A.; Adam, M.S. and Abdel-Basset, R. (1998). Effect of $\mathrm{Ca}^{2+}$ on the detoxification of $\mathrm{Cd}^{2+}$ by Scenedesmus obliquus cells at lower or high temperature. Folia Microbial, 43: 643-648.

Issa, A.A.; El-Enany, A.E. and Abdel-Basset, R. (2002). Modulation of the photosynthetic source: sink relationship in cultures of the Cyanobactacterium Nostoc rivulare. Biologia Plantarum, 45: 221-225.

Issa, A.A; Adam M.S.; Hifney A.F. and Al-Abssy A.A. (2006). Seasonal variation of crust algae on the great sub-group of soil at Assiut Governorate. J. of Botany Assiut Uni., 35:127-147.

Jensen, T.E.; Rachlin, J.W.; Jani, V. and Warkentine, B. (1982). An X-ray energy dispersive study of cellular compartmentalization of lead and zinc in Chlorella saccharophila (Chlorophyta), Navicula incerta and Nitzschia closterium (Bacillariophyta). Environ. Exp. Bot., 22: 319-328.

Kelemen, J. and Csordas, E. (1994). Lead content of roadside plants. In $2^{\text {nd }}$ International Symposium, Animal Scientific Days, Actual Problems in Development to Livestock Production, Rovin, Goatia, 21-23 September 1994. Znanosti Praksau Doljoprivedii Preharmbenoj Technoloigii, 24: 167-173 (c.f.) Soil and Fert., 59: Abst. (10359).

Lee, Y.D. and Takahashi, T. (1966). An improved colorimetric determination of amino acids with use of ninhydrin. Anal. Biochem, 14: 71-77.

Lefort-Tran, M.; Pouphile, M.; Spath, S. and Packer, L. (1988). Cytoplasmic membrane changes during adaptation of the freshwater cyanobacterium Synechococcus 6311 to salinity. Plant Physiol., 87: 767-775.

Lowry, D.H.; Rosebrough, N.J.; Farr, A.L. and Randall, R.J. (1951). Protein measurement with the folin phenol reagent. J. Biol. Chem., 193: 265-275.

Marker, A.F.H. (1972). The use of acetone and methanol in the estimation of chlorophyll in the presence of Phaeophytin. Fresh Wat. Biol., 2: 361-385.

McGrath, S.P. (1987). In pollutant transport and fate in ecosystem. Special publication No. 6 of the British Ecology Society. Blackwell Scientific, Oxford, pp. 301-317. 
McGrath, S.P. (1995). Chromium and Nickel. In: "Heavy metals in soils". $2^{\text {nd }}$ ed by B.J. Alloway. Blackie Academic and Professional, pp. 152-177.

Mendoza-Cozatl, D.; Devars, S.; Loza-Tavera, H. and Moreno-Sânchez, R. (2002). Cadmium accumulation in the chloroplast of Euglena gracilis. Physiol. Plantarum., 115: 276-283.

Metzner, H.; Rau, H. and Senger, H. (1965). Untersuchungen zur synchronisier-barkeit ein zelner pigment managel. Mutanten von Chlorella. Planta, 65: 186-194.

Nikolopoulos, D. and Manetas, Y. (1991). Compatible solutes and in-vitro stability of Salsola soda enzymes: proline incompatibility. Phytochemistry, 30: 411-413.

Nriagu, T.O. and Pacyna, J.M. (1988). Quantitative assessment of worldwide contamination of air, water and soils by trace-metals. Nature, 333: 134139.

Pelah, D.; Wang, W.; Altman, A.; Shoseyov, O. and Bartels, D. (1997). Differential accumulation of water stress-related proteins, sucrose and soluble sugars in Populus species that differ in their water stress response. Physiol. Plant, 99: 153-159.

Rachlin, J.W.; Jensen, T.E. and Warkentine, B. (1983). The growth response of the diatom Nivicula incerta to selected concentrations of metals, cadmium, copper, lead and zinc. Bulletin of the Torrey Botanical Club, 110: 217-223.

Rashed, I.F.; Abdel Nabi, A.O.; El-Hemely, M.E. and Khalaf, M.A. (1995). Background levels of heavy metals in the Nile Delta soils. Egypt. J. Soil. Sci., 35: 239-252.

Rippka, R. and Herdman, M. (1993). Pasteur culture collection of cyanobacterial strains in axenic culture. Vol. 1 Catalogue of Strains 103 P., Institut. Pasteur, Paris, France.

Robidoux, P.Y.; Gong, P.; Sarrzin, M.; Bardai, G.; Paquet, L.; Hawari, J.; Dubois, C. and Sunahara, G.I. (2004). Toxicity assessment of contaminated soils from an antitank firing range. Ecotoxicology and Environmental Safety, 58: 300-313.

Sabnis, D.D.; Gordon, M. and Galston, A.E. (1969). A site with an affinity for heavy metals on the thylakoid membranes of chloroplast. Plant Physiol., 44: 1355-1363.

Say, P.J. and Whitton, B.A. (1982). Chemistry and plant ecology of zinc-rich streams in France. 2. The Pyrênêes. Annals. Limmol., 18: 19-31.

Schlegel, H.G. (1956): Die verwertung organischer sauren duch Chlorella in licht. Planta, 117: 510-526. 
Siripornadulsil, S.; Traina, S.; Verma, D.P.S. and Sayre, R.T. (2002). Molecular mechanisms of proline-mediated tolerance to toxic heavy metals in transgenic microalgae. The Plant Cell. 14: 2837-2847.

Takamura, N.; Kasai, F. and Watanabe, M.M. (1989). Effects of Cu, D and Zn photosynthesis of freshwater benthic algae. J. of Appl. Phyco., 1: 39-52.

Vitraella, D.; Conklin, D.R.; Kimelberg, H.K. and Aschener, M. (1996). Metallothionein induction protects swollen rat primary astrocyte cultures from methylmercury-induced inhibition of regulatory volume decrease. Brain Res., 738: 213-221.

Wehr, J.D. and Whitton, B.A. (1983). Aquatic cryptogams of natural acid spring enriched with heavy metals: kootenay paint pots. British Columbia, Hydrobiologia, 98: 97-105.

Wu, J.T.; Chang, S.J. and Chou, T.L. (1995). Intracellular proline accumulation in some algae exposed to copper and cadmium. Bot. Bull. Acad. Sinica, 36: 89-93.

Wu, J.T.; Hsieh, M.T. and Kow, L.C. (1998). Role of proline accumulation in response to toxic copper in Chlorella sp. (Chlorophyceae) cells. $J$. Phycol., 34: 113-117.

Xu, D.; Duan, X.; Wang, B.; Hong, B.; Ho, T.D. and Wu, R. (1996). Expression of a late embryogenesis abundant protein gene, HVAI, from barley contents tolerance to water deficit and salt stress in transgenic rice. Plant Physiol., 110: 249-257.

Yaron, B.; Calvet, R. and Prost, R. (1996): Soil population processes and dynamics. Springer-Verlag Berlin Heidelberg, New York, pp. 313.

Yupsanis, T.; Moustatkas, M.; Eifftheriou, P.I. and Damianidou, K.L. (1994). Protein phosphorylation - dephospho-relation in alfalafa seeds germinating under salt stress. J. Plant Physiol., 143: 234-244.

Zenk, M.H. (1996). Heavy metal detoxification in higher plants: A review. Gene, 179: 21-30. 
الخلل في المسارات الايضية لبعض عزلات طحالب التربة كاستجابة لسمية العناصر الثقيلة

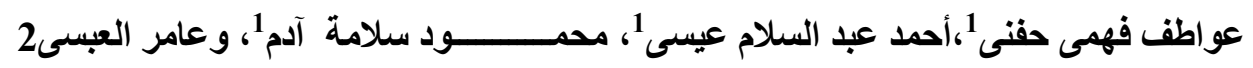

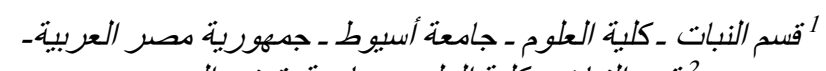

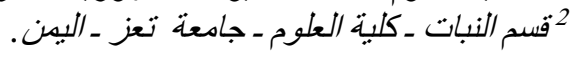

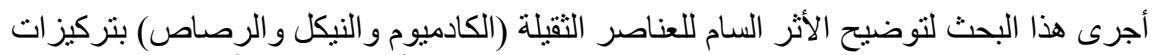

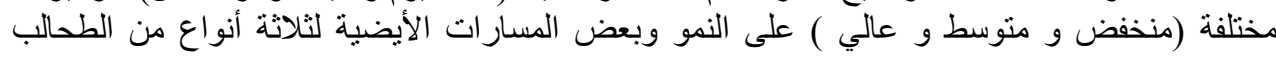

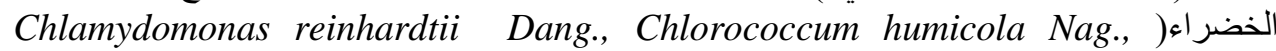
Anabaena (Scenedesmus obliquus(Turp)Kütz (circinalis Rabh and Wollea saccata (Wolle) Bornet and Flahault.

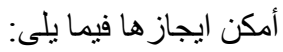

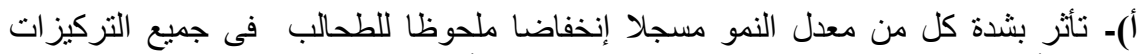

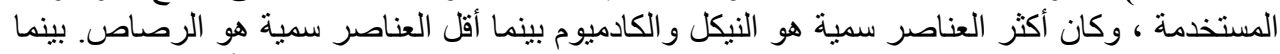
سجل معدل النمو زيادة ملحوظة لطحلب Anabaena circinalis باستخدام التركيز الأدنى و المتوسط من النادئ

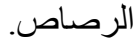

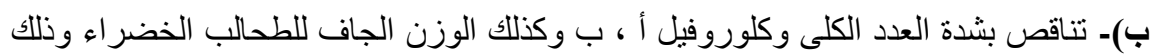

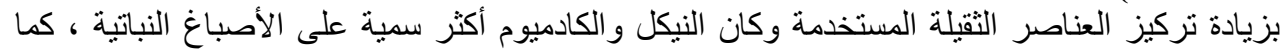

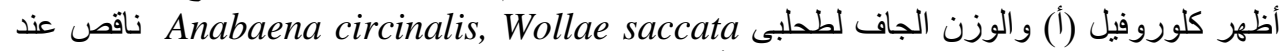
استخدام الكادميوم والنيكل وزاد كلوروفيل (أ) فى Wollea saccata زيادة طفيفة باستخدام عنصر

ج)- كان معدل السمية فى الطحالب الخضر اء بالعناصر الثقبلة المستخدمة على النحو التالى: النيكل ثم الكادميوم ثم الرصاص ، بينما تغير فى Anabaena circinalis إلى الكادميوم ثم النيكل ثم الثم

د)ـ تناقص معدل البناء الضوئى لجميع الطحالب بزيادة تركيز العنصر النقيل المستخدم وازداد

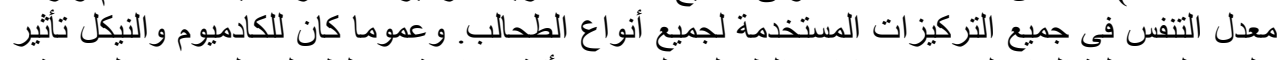

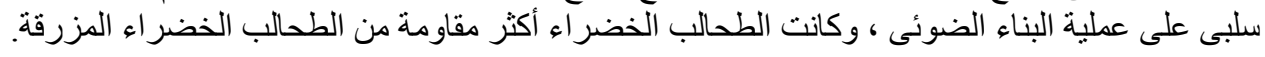

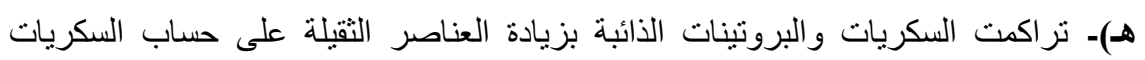
و البروتينات غير الذائبة فى جميع الطحالب قيد الدراسة.

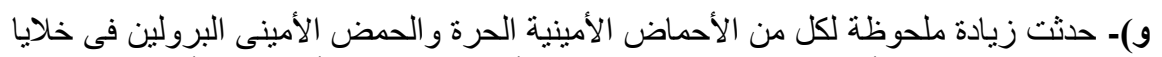

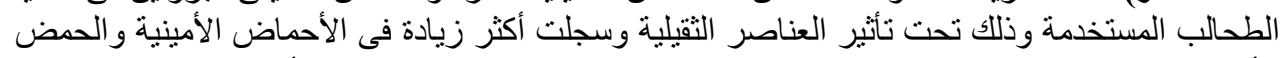

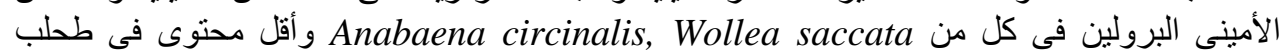

.Scenedesmus obliquus

و اخير ا يجدر الاشارة الى ان العناصر الثقيلة الثناثة المستخدمة احدثت تثنيطا فى النمو ومعظم

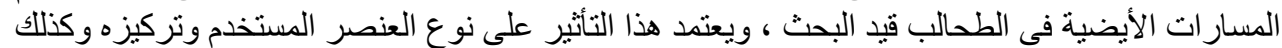

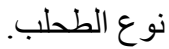

